\title{
Sir Barnes Wallis — 1887-1979
}

I FIRST heard of Wallis in 1920 , when the airship R 80, for the design of which he was responsible, began its trials. In retrospect, this was the most successful rigid airship designed in this country but the Air Staff decided that they had no use for it and it flew for the last time on 20 September 1921. As a result of this decision, Wallis was forced to leave the world of design in which he had already, at the age of 34 , proved himself a master. He took up teaching in Switzerland and began his courtship of the lady who was to become his wife. In 1923 however a new association with rigid airship design began. Another remarkable man, Commander (and ultimately Sir) Dennistoun Burney, had been at work during Wallis's absence abroad, gaining support for his airship project. The result of Burney's persistence was the creation of the Airship Guarantee Company, a Vickers subsidiary headed by himself with headquarters at Howden in Yorkshire, and the renaissance of the Royal Airship Works at Cardington. Wallis became the chief designer at Howden and at Cardington the design team was led by V.C. Richmond. The Air Ministry gave the Airship Guarantee Company the task of building R 100 and the Royal Airship Works the task of building R 101 .

In 1924 work began in earnest on both designs. In outline they were similar, each five times as long as its greatest diameter, with that diameter at $40 \%$ of the length from the nose. They were both to hold $5,000,000 \mathrm{cu}$.ft. of hydrogen. In 1924 there also began an absurd segregation of the two design teams. I was conscious of it almost from my first day at Cardington, in July 1924. That a tremendous competition should begin in that year was inevitable, and indeed desirable, but that each team should find itself with a boundary wall round it, and have no opportunities to compare notes and progress, was absurd and damaging: each team would have benefited by knowledge of the ideas and progress of the other. Where the blame for this situation, which rapidly developed and was sustained to the end - the end of R 101 - should lie I am uncertain. Wallis, already a successful airship designer, highly individualistic, formidable in his belief - not unjustifiable - in his own ideas, was almost the antithesis of Richmond, whose experience had been with non-rigid airships and whose merits were rather those of a manager and a talent-spotter than of an aircraft designer. Each was scornful of the other's efforts. In my five years at Cardington I do not think they ever met. But the long-range animosity - it was no less - was fostered by others, and if Richmond was no genius as Wallis was, he nevertheless had an eminence grise, Flt Lieut. (later Sqdn Leader) F.M. Rope at his elbow whom, had Wallis ever met him, he would have had to admit to his own extraordinary intellectual level.

In $\mathrm{R} 100$ Wallis, I believe for the first time, exhibited his passion for helices. The main booms of the heavy triangular section girders were made by rivetting duralumin strip on itself to produce a tube resembling a paper drinking straw. Wallis designed the special rivetting machine for the job. The wiring conveying the lift of the gasbags to the joints of the structure was a system of helices - or, more accurately, geodetics in which the mesh became finer as the height from the bottom of the ship, and hence the gas pressure, increased. The affection for the helix, which in Wallis's hands produced elegant solutions to structural problems, manifested itself even more dramatically in his two most famous aeroplanes, the Wellesley and the Wellington.

Before the splendid flight of R 100 across the Atlantic and back in the summer of 1930, Wallis had been persuaded by Sir Robert McLean, the managing director of Vickers, to leave Howden and join the aircraft design side of Vickers. His first appointment was at the Supermarine works at Southampton where he did not cooperate successfully with another remarkable man, R.J. Mitchell, the designer of the Spitfire. After a few months he was moved to Weybridge to work alongside still another great man, R.K. Pierson, famous for a whole series of aircraft, including the Vimy which made the first transatlantic flight in 1919. They were both ranked as Chief Designer.

The association of Pierson and Wallis was a complete success. Pierson was a big man, in physique and in character: soon Wallis, four years the elder, whom at this time I began really to know, called him Uncle Rex, which I think defined Pierson's relations with the major personality so suddenly thrown into close association with him.

While Wallis was back at Howden during the preparations for $\mathbf{R} 100$ 's Atlantic venture, he was not allowed by McLean to fly in her, which seems a little hard. But by the time he had left Howden for Southampton, Wallis indeed had already begun to doubt the future of the airship in the face of the dramatic progress of the aeroplane, so perhaps he did not feel the deprivation too deeply. He was soon back at Weybridge thinking about aeroplanes and developing the system of geodetic construction. 
At that time I was working on criteria defining the stiffness characteristics of aeroplane wings necessary for avoiding wing flutter and loss of aileron control due to wing twisting. Wallis came to see me and said, in effect, "Tell me how stiff to make my Wellesley wing and I will make it that stiff and no more". I told him and he did indeed achieve the minima I prescribed with a structure which was extremely light. The structure weight he achieved was well below what was being achieved in wings of more conventional construction.

I have never been convinced that Wallis's geodetic system was intrinsically superior to more conventional systems. It was superior in practice because he designed extremely efficiently to the prescribed limits. I have no recollection of any other designer of those days seeking at the outset of his design to discover the stiffness limits to which he should design. Even if I do dare to doubt the intrinsic superiority of geodetic construction however, I certainly do not deny its elegance. It had moreover a tremendous advantage in battle. The fact that strength and stiffness were, so to speak, distributed in what was almost a skin of geodesic mesh meant that the structure had few weak points, and gunfire from the ground and from the air might knock great holes in the structure without wrecking it. So triumphant was it that one might well ask why it did not persist as a basic system for aircraft construction. The answer is that the whole trend of design was away from frameworks covered with fabric and towards all metal monocoque construction. That is why the Wellesley and the Wellington were never emulated, even by Wallis himself.

The Wallis I knew was never the arrogant prickly person we of the $\mathrm{R} 101$ design team were led to visulise. Certainly his was a strong character, certainly he was firm in his views, but equally certainly he knew his limits and did not hesitate to seek help in areas beyond them - as when he sought my aid on wing stiffness - and I am sure he sought Pierson's aid, particularly on the aerodynamic side of his designs. He was indeed sometimes critical of others working in his own areas of expertise, but who is not? I always found him supremely articulate, subtly persuasive and invariably polite, all in a voice it was a pleasure to listen to. I found him, too, appreciative of the work of others. I recall that it was with some trepidation that I took him, at his request, to Hucclecote to see the drawings of the Gloster E 28/39 which Carter was designing for the first flight of the Whittle jet engine. I thought there might be questions of the "Why didn't you do it this way?" kind. There were not. Carter was completely open - he displayed all his ideas and Wallis had nothing but commendation then and afterwards.

I had no contact with Wallis on the Mohne and Eder dambusting bomb nor its massive successor. But I was in touch, as an occasional visitor to Weybridge, with his ideas on the swing wing or variable geometry aeroplane and bitterly disappointed at the lack of support for his ideas. The swing wing has been with us for some years now, but had it been adopted in practice when Wallis showed the way this country would have had a commanding technological lead in a new field: once again, we threw away a golden opportunity.

In his office on the old Brooklands track, and after his retirement from
Vickers in his home, he always worked out his ideas himself on his drawing board. Obviously, on his great projects, he directed the work of others. But the intricacies of joints in geodetic meshes, the details of the pivot of a swing wing, were elucidated on his own board. It was the same to the end: when I last saw him in his house at Effingham he was working on his board on very high speed vehicles indeed. I can only hope his efforts to bring these last visions to reality will not be wasted.

I have made no attempt in these notes to chart the long life of Barnes Neville Wallis, from his birth on 26 September 1887, to his death on 30 October 1979. The fullest account, up till 1970, is Mr Morpurgo's biography $^{1}$. I do not agree with quite all of Mr Morpurgo's judgements - nor indeed with quite all of those he attributes to Wallis - but factually it is a vivid and accurate account of a great man's life and I hope the biographer will add a chapter to complete the story. In that book we can read the true account of how Wallis was awarded by the Royal Commission on Awards to Inventors $£ 10,000$ for his dambusting bomb, and how he applied that sum to the creation of a foundation at his old school, Christ's Hospital - of which he was Treasurer from 1957 to 1970 . This splendid act illumines facets of Wallis's character with which the world in which he became famous was unfamiliar - his loyalty, his generosity, indeed his unselfishness. In total he was a great and good man. We who knew him were greatly privileged.

Kings Norton

1. Morpurgo, J.E. Barnes Wallis: A Biography. (Longman, London 1972)

\section{Wolfgang Yourgrau}

Wolfgang H.J. YOURGRAu died suddenly at his home in Denver, Colorado, USA, on 18 July 1979, at the age of 70 , shortly after returning home from an extended tour of lecturing and research in Europe. His passing marks the disappearance from the world of physics and the philosophy of science of a colourful scholar and humanist, whose diverse talents and activities have left enduring imprints far outside the field of his speciality.

Wolfgang Yourgrau was born on 16 November 1908 near Berlin of a Belgian father and a German-Jewish mother. He attended the Werner-Siemens Realgymnasium in Berlin and subsequently studied theoretical physics, mathematics, and biology at the local von Humboldt University, at a time when celebrated physicists such as von Laue, Einstein, and Schrödinger graced its Faculty. Serving first as a tutor in natural philosophy and then as an assistant to Schrodinger, he earned his Dr phil. magna cum laude in
1932, the terminal year of the Weimar Republic.

The next year saw the ascendancy to power of the Nazis, and Yourgrau, who got their attention as an organizer of the S.A.P. (an offshoot of the German Social Democratic Party), fled Germany after being severely beaten up by the Storm Troopers. In exile, he remained on the move while lecturing on the evils of fascism in Latvia, Poland, and other European countries, until he was allowed to enter Palestine, then a British mandate, as a political refugee.

Appointed a lecturer with the educational and cultural division of the Histadrut (Jewish Federation of Labor), he travelled widely inside Palestine and became drawn into discussions on the intractable problems of this territory. But Nazism, its devastation of the cultural values in which his family had been rooted for centuries, and then the daily progress of World War 2 remained foremost in his mind. In the Spring of 1942 he acquired from the British authorities a license to publish Orient, an independent German- language weekly, with himself as Editor-inChief and Arnold Zweig, the renowned novelist-dramatist and a fellow exile, as copublisher. Under Yourgrau's direction, Orient - which has lately become the subject of detailed analyses by some literary historians - declared war "on every fascist movement, every attempt to restrict the right to free expression of opinion .... ." But it was a subsidiary point on the programme of Orient, touching on the complex internal politics of Palestine, which made the journal a centre of intense controversy. Boycotts and threats against businesses connected with Orient and finally destruction of the premises of its fourth printer caused the financially plagued journal to close down for good in 1943, one year after its inception.

Yourgrau lost no time in assuming a more active role in the war against the Axis Powers, which was then increasingly being fought in the Mediterranean theatre. At first, working from an office of the Palestine Information Office, this only meant preparing the news bulletins in 